\title{
STUDI TINGKAT PENGETAHUAN IBU TENTANG KARIES GIGI PADA ANAK USIA PRA SEKOLAH DI PERUMAHAN CITRA GADING SUKODONO SIDOARJO
}

\author{
Riesmiyatiningdyah $^{1}$, Jamaludin ${ }^{1}$, Okki Agung Rahmawati ${ }^{1}$ \\ ${ }^{1}$ Akademi Keperawatan Kerta Cendekia Sidoarjo
}

Corresponding: miyati_miyati@yahoo.com

\begin{abstract}
Abstrak
Introduction. Karies gigi merupakan penyakit yang paling banyak dijumpai di rongga mulut bersama-sama dengan penyakit periodontal, sehingga merupakan masalah utama kesehatan gigi dan mulut. Fenomena yang ada,banyak ibu yang belummengerti karies gigi dan banyak ibu yang bekerja. Tujuan penelitian ini adalah untuk mengetahui tingkat pengetahuan ibu tentang karies gigi pada anak usia pra sekolah. Methods. Metode penelitian yang digunakan adalah Deskriptif. Populasi yang digunakan dalam penelitian ini adalah $50 \mathrm{Ibu}$. Teknik sampling yang digunakan adalah total sampling. Teknik pengumpulan data menggunakan kuisioner dengan jumlah pertanyaan 15 soal. Setelah data terkumpul dilakukan tabulasi dalam bentuk tabel distribusi frekuensi. Data diinterpretasikan sehingga menghasilkan suatu kesimpulan. Results. Hasil penelitian menunjukan bahwa responden dengan tingkat pengetahuan kurang sebanyak $25 \mathrm{Ibu}(50 \%)$. Discussion. Maka perlu ditingkatkan dengan pendidikan kesehatan, memberikan penyuluhan dari petigas kesehatan di posyandu.
\end{abstract}

Keywords: Pengetahuan, Ibu, Karies gigi

\section{Pendahuluan}

Karies gigi merupakan penyakit yang paling banyak dijumpai dirongga mulut bersama-sama dengan penyakit periodontal, sehingga merupakan masalah utama kesehatan gigi dan mulut. Penyakit ini ditandai dengan kerusakan jaringan, dimulai dari permukaan gigi dan meluas kearah pulpa(Susanto, 2009). Penyakit ini sering di jumpai pada anak-anak prasekolah, karena anak sudah bisa mengenal makanan, biasanya mereka paling suka jajan diluar dan makan yang manis-manis tetapi mereka tidak mengimbanginya dengan menggosok gigi, karena peran orang tua dalam mengontrol untuk menggosok gigi sangat kurang. Hal ini dapat terjadi, karena pengetahuan orang tua sangat kurang atau orang tua yang bekerja sehingga anak di titipkan kepada saudara atau tempat penitipan anak(Elva Kadarhadi, 2002). Fenomena yang ada di perumahan Citra Gading, banyak anak-anak usia prasekolah yang mengalami karies gigi. Hal itu disebabkan karena banyak orang tua yang bekerja sehingga anak dititipkan oleh saudara atau tempat penitipan anak. Sehingga anak sulit dikontrol atau diawasi dalam hal membeli makanan seperti permen, coklat, dan sebagainya. Padahal anak-anak paling malas untuk menggosok gigi setelah makan, sehingga anak-anak mengalami karies gigi. Masalah yang timbul akibat karies gigi ini banyak anak - anak yang sering menangis dan memegang pipinya. Sehingga banyak anak - anak yang tidak masuk sekolah karena mengeluh giginya sakit.

Kasus karies gigi di Indonesia masih terbilang tinggi. Menurut data kementrian kesehatan RI, bahwa prevalensi karies di Indonesia mencapai $60-80 \%$ dari populasi, serta menempati peringkat keenam sebagai penyakit yang paling banyak diderita. Diperkirakan bahwa 90\% dari anak-anak usia sekolah di seluruh dunia dan sebagian besar orang dewasa pernah menderita karies. Prevalensi karies tertinggi terdapat di Asia dan Amerika Latin. Prevalensi terendah terdapat di Afrika. Di Amerika Serikat, karies gigi merupakan penyakit kronis anak-anak yang sering terjadi dan tingkatnya 5 kali lebih tinggi dari asma. Karies merupakan penyebab patologi primer atas penanggalan gigi pada anak-anak.

Faktor pendidikan, pengalaman, media informasi, dan sebagainya mempengaruhi baik atau kurangnya tingkat pengetahuan Ibu tentang karies gigi pada anak pra sekolah. Kurangnya tingkat pendidikan ibu dan keluarga serta minimnya informasi kesehatan tentang karies gigi menjadi faktor dominan yang menyebabkan kurangnya pengetahuan ibu tentang cara menjaga kesehatan gigi yang baik. Akibatnya banyak anak-anak yang sehabis makan tidak menggosok gigi. Bila hal ini dibiarkan, maka akan beresiko bertambah parahnya karies gigi yang diderita oleh anak-anak. Konsep solusi yang dapat dilakukan untuk mengatasi masalah ini adalah dengan memberikan penjelasan dan informasi tentang kesehatan gigi.

\section{Metode dan Bahan}

Dalam penelitian ini desain yang digunakan adalah deskriptif case studi atau studi kasus yang menggambarkan tentang cara meneliti suatu permasalahan melalui suatu kasus yang terdiri dari unit tunggal. Unit tunggal disini dapat berarti satu orang, kelompok penduduk yang terkena suatu masalah (Setiadi, 2007). Penelitian ini dilakukan di Perumahan Citra Gading Sukodono Sidoarjo pada 15 - 16 Maret 2016. Populasi dalam penelitian ini adalah Ibu yang 
mempunyai anak usia pra sekolah di Perumahan Citra Gading sebanyak 50 orang. Teknik sampling yang dipergunakan adalah total sampling sehingga seluruh populasi penelitian akan diambil sebagai responden. Pengumpulan data dengan menggunakan kuesioner. Instrumen penelitian yang digunakan dalam pengumpulan data pada penelitian ini adalah dengan menggunakan kuesioner jenis close ended question dengan jumlah 15 pertanyaan pengetahuan ibu tentang karies gigi terhadap anak usia pra sekolah (3-6 tahun). Setelah data terkumpul, peneliti melakukan analisis dengan tahapan editing, coding, scoring, tabulasi.

\section{Hasil Penelitian}

Berdasarkan data hasil penelitian didapatkan bahwa 50 responden, 25 orang $(50 \%)$ mempunyai pengetahuan yang kurang tentang karies gigi dan 9 orang (18\%) mempunyai pengetahuan baik. Hasil penelitian tersebut disajikan dalam tabel 3.1.

\section{Pembahasan}

Berdasarkan hasil penelitian, dapat diketahui bahwa secara umum ibu yang mempunyai anak usia pra sekolah memiliki tingkat pengetahuan yang kurang tentang karies gigi. Hal ini terbukti dari data hasil penelitian pada tabel 4.5 di peroleh yaitu sebanyak 25 orang $(50 \%)$ memiliki tingkat pengetahuan kurang. Menurut pendapat peneliti, tingkat pengetahuan kurang dalam menangani karies gigi ini dapat di pengaruhi oleh beberapa factor, diantaranya usia, pendidikan, pekerjaan, dan jumlah anak. Seperti yang diungkapkan oleh Notoatmodjo (2010), pengetahuan seseorang dapat di pengaruhi oleh usia, intelegensi, lingkungan, social budaya, pengalaman, pendidikan, informasi, media massa, dan media elektronik.

Semakin bertambahnya umur pengetahuan yang di dapat semakin rendah. Hal ini bias di karenakan beban yang ada pada ibu semakin banyak sehingga informasi yang di dapat tidak bisa di tangkap dengan baik atau karena daya ingat menurun. Menurut Notoatmodjo (2005) usia merupakan salah satu faktor yang mempengaruhi pengalaman seseoarang, semakin bertambahnya usia semakin banyak pengalaman yang dimiliki sehingga memiliki pengetahuan yang cukup sesuai dengan pengalaman yang dimilikinya.

Semakin tinggi tingkat pendidikan yang didapat dapat memberikan pengaruh baik pada ibu karena pola pikir ibu yang berpendidikan tinggi dapat berfikir secara luas dan mencari informasi sendiri tentang masalah karies gigi, sehingga bila terjadi karies pada anak dapat dengan cepat diatasi.. Sesuai dengan pernyataan Notoatmodjo (2010) yang menyatakan bahwa semakin tinggi tingkat pendidikan seseorang makin mudah menerima infomasi sehingga makin banyak pula pengetahuan yang dimiliki. Sebaliknya pendidikan yang kurang akan menghambat perkembangan pengetahuan seseorang terhadap nilai-nilai yang baru diperkenalkan.
Tabel 3.1 Tabel distribusi frekuensi responden menurut tingkat pengetahuan ibu dalam menghadapi karies gigi pada anak pra sekolah Maret 2016

\begin{tabular}{|c|c|c|}
\hline $\begin{array}{c}\text { Tingkat Pengetahuan } \\
\text { Ibu }\end{array}$ & Frekuensi & $\%$ \\
\hline Baik & 9 & 18 \\
\hline Cukup & 16 & 32 \\
\hline Kurang & 25 & 50 \\
\hline Total & 50 & 100 \\
\hline
\end{tabular}

Pekerjaan dapat mempengaruhi tentang informasi karies gigi, semakin padatnya kesibukan ibu semakin tidak memperdulikan informasi tentang karies gigi sehingga bila terjadi karies gigi pada anak, ibu hanyak menyuruhnya untuk gosok gigi. Maka jika itu dibiarkan maka karies gigi semakin bertambah besar. Menurut Azwar, S. (2008), yang menyatakan interaksi social pada seseorang tidak berkaitan dengan pengetahuan maupun informasi, mengakibatkan seseorang kurang memperoleh pengetahuan ataupun informasi dan semakin banyak pekerjaan seseorang semakin banyak pula pekerjaan yang harus diselesaikan sehingga waktu untuk mencari suatu info sulit dikarenakan kesibukannya.

Seorang ibu yang mempunyai anak $>2$ sudah mempunyai banyak pengalaman dari anak sebelumnya oleh karena itu pengetahuan tentang karies gigi lebih baik dan mungkin dari anak sebelumnya juga pernah menderita karies gigi. Pengalaman adalah suatu peristiwa yang dialami seseorang (Brook, 2009) yang dikutip oleh Azwar (2009) mengatakan bahwa tidak adanya suatu pengalaman sama sekali. Suatu objek psikologis cenderung akan bersikap negatif terhadap objek tersebut untuk menjadi dasar pembentukan pengetahuan, pengalaman pribadi haruslah meninggalkan kesan yang kuat. Karena itu pengetahuan akan lebih mudah terbentuk apabila pengalaman pribadi tersebut dalam situasi yang melibatkan emosi, penghayatan, pengalaman akan lebih mendalam dan lama membekas.

\section{Simpulan}

Pada bab ini akan disajikan kesimpulan dari hasil penelitian studi tingkat pengetahuan ibu tentang karies gigi pada anak usia pra sekolah di perumahan citra gading sukodono sidoarjo. Berdasarkan data hasil penelitian, maka dapat disimpulkan bahwa dari 50 responden didapatkan setengah responden yaitu 25 (50\%) yang memiliki tingkat pengetahuan kurang.

\section{Saran}

Berdasarkan hasil penelitian tersebut diharapkan responden agar dengan rutin membawa anak untuk memeriksakan giginya 6 bulan sekali dan 
banyaklah bertanya pada petugas kesehatan tentang karies gigi. Diharapkan tenaga kesehatan terkait membuat program penyuluhan tentang karies gigi, tanda dan gejala, dan cara mengatasinya agar tercipta pengetahuan yang baik dalam mengatasi karies gigi pada anak. Selain itu, hasil penelitian ini dapat digunakan sebagai referensi tentang kesehatan yang berhubungan dengan karies gigi yang diharapkan dapat membantu dalam proses belajar mengajar. Diharapkan peneliti selanjutnya mampu mengembangkan dan melakukan penelitian yang sama pada masyarakat lain dengan memvalidasi angket atau kuesioner terlebih dahulu dan menggunakan jumlah sampel yang lebih banyak serta metodologi penelitian yang lebih baik sehingga hasilnya dapat lebih representatif untuk direalisasikan.

\section{Daftar Pustaka}

Arikunto, Suharsini. (2002). Prosedur Penelitian Suatu Pendekatan Praktek. Jakarta: Rineka Cipta

Arikunto, S. 1998. Prosedur Penelitian Suatu Pendekatan Praktek. Jakarta: Rineka Cipta.

Effendi, Nasrul. 1998. Dasar-dasar Keperawatan Kesehatan Masyarakat. Jakarta: EGC.

Nursalam. 2003. Konsep Dan Penerapan Metodologi Penelitian Ilmu Keperawatan. Jakarta: Salemba Medika.

Notoatmodjo,S. 2005. Metodologi Penelitian Kesehatan.Jakarta: Rineka Cipta.

Setiadi, 2007. Konsep dan Penulisan Riset Keperawatan. Yogyakarta: Graha Ilmu.

Soetjiningsih. 1998. Tumbuh Kembang Anak. Jakarta : EGC

Nurmala Situmorang Tampubolon. (2005). Dampak Karies Gigi dan Penyakit Periodontal Terhadap Kualitas Hidup. Library,usu.ac.id. Diakses pada tanggal 20 September 2013 pada pukul 20.15 WIB

Ratnawati Hendari. (2011). Pengertian Karies Gigi. http://ratnawati_hendari.blogspot.com. Diakses pada tanggal 20 September 2013 pada pukul 20.40 WIB

Rahmadhan, Ardyan Gilang. (2010). Serba Serbi Kesehatan Gigi dan Mulut. Jakarta: Bukune.

Somantri, Ateng dan Sambas Ali Muhidin. (2006). Aplikasi Statistika dalam Penelitian. Bandung: Pustaka Setia.

Sulistyoningsih, Hariyani. (2011). Gizi Untuk Kesehatan Gigi Ibu dan Anak. Yogyakarta: Graha Ilmu.

Enung, F. Psikologi perkembangan : perkembangan Peserta didik. 2006. Bandung: CV Pustaka Setia. 